\title{
PERAN PENDAMPING TERHADAP PEMBERDAYAAN KELOMPOK TANI KAKAO DI KABUPATEN BOLAANG MONGONDOW UTARA
}

\author{
Juwita Janeke Eman \\ Jenny Baroleh \\ Agnes E. Loho
}

\begin{abstract}
ABSRACT
This study aims to determine the role of facilitators who facilitate farmer groups, especially in cocoa crops and know the various obstacles faced by the accompaniment in the assistance activities of cocoa farmer groups in North Bolaang Mongondow Regency. The study lasted for three months from February to April 2017. The data collected in the form of primary and secondary data. Primary data collected through interviews with 5 farmer groups and taken by deliberate were 3 farmers group of Advanced and 2 groups of Beginner Farmer Group. Each group of farmers is taken as many as 6 people consisting of the management of farmer groups namely chairman, secretary, treasurer and 3 members. Total of respondents amounted 30. Secondary data were obtained from the Office of Agriculture and District Offices in North Bolaang Mongondow. Data analysis was used descriptive analysis. The results of this research showed that the counselor was instrumental in empowering the cocoa farmer groups in both the beginner and advanced farmer groups in intensification and rehabilitation activities. The role of companion is categorized as a very important role that is $88.3 \%$. This can be seen from the corective and enhacement in the way of gardening. The constraints faced by counselors, especially at the beginner level farmers, are the fear of to take risk of failure in production so that they have not dared to try new technologies.
\end{abstract}

Keywords: Cocoa, Empowerment, farmer group, North Bolaang Mongondow Regency

ABSTRAK

Penelitian ini bertujuan untuk mengetahui peran pendamping yang memfasilitasi kelompok tani khususnya pada tanaman kakao dan mengetahui berbagai kendala yang dihadapi oleh pendamping kakao di Bolaang Mongondow Utara. Penelitian berlangsung selama tiga bulan mulai dari bulan Februari sampai April 2017 di Kabupaten Bolaang Mongondow Utara. Data yang dikumpulkan berupa data primer dan sekunder. Data primer yang dikumpulkan melalui wawancara dengan 5 kelompok tani dan di ambil secara sengaja yaitu 3 kelompok tani Kelas Lanjut dan 2 kelompok tani Kelas Pemula. Masing-masing kelompok tani diambil sebanyak 6 orang yang terdiri atas pengurus kelompok tani yaitu ketua, sekretaris, bendahara dan 3 orang anggota sehingga jumlah keseluruhan sebanyak 30 responden. Data sekunder diperoleh dari kantor Dinas Pertanian dan Kantor Kabupaten di Bolaang Mongondow Utara. Metode analisis yang digunakan yaitu secara deskriptif. Hasil penelitian menunjukkan bahwa pendamping sangat berperan dalam pemberdayakan kelompok tani kakao baik pada kelompok tani tingkat pemula maupun tingkat lanjut dalam kegiatan intensifikasi dan rehabilitasi. Peran pendamping tergolong pada kategori sangat berperan yaitu $88,3 \%$ karena petani kakao merasa sangat terbantu dengan adanya kegiatan pendampingan pada kelompok tani. Hal ini terlihat dari adanya perbaikan dan peningkatan dalam cara berkebun sebagai hasil dari adanya pendampingan. Kendala yang dihadapi oleh pendamping, terutama pada kelompok tani tingkat pemula, yaitu adanya rasa takut akan resiko gagal dalam produksi sehingga belum berani mencoba teknologi-teknologi baru yang diperkenalkan dan lebih memilih untuk mengusahakan tanaman seperti yang selama ini mereka lakukan. Pendamping masih sulit merubah pola pikir petani agar petani dapat lebih mandiri dan tidak tergantung pada bantuan dari pemerintah saja.

Kata kunci: Coklat, Pemberdayaan, Kelompok Tani, Pendamping, North Bolaang Mongondow 


\section{PENDAHULUAN}

\section{Latar Belakang}

Peran pemerintah dalam pemberdayaan masyarakat, khususnya petani telah dilaksanakan oleh dinas terkait yang tertuju pada keberlanjutan kelompok tani. Pemberdayakan masyarakat adalah upaya untuk meningkatkan harkat dan martabat lapisan masyarakat yang dalam kondisi sekarang tidak mampu menjadi mampu untuk melepaskan diri dari perangkap kemiskinan dan keterbelakangan. Donni (2016) mengartikan bahwa pemberdayaan merupakan suatu usaha proses menjadikan untuk membuat mampu, membuat dapat bertindak atau melakukan sesuatu, baik sikap maupun perilaku. Pemberdayaan kelembagaan petani berdasarkan undang-undang nomor 16 tahun 2006 pada pasal 9, kelembagaan petani meliputi kelompok tani asosiasi dan koorporasi. Kebijakan pemberdayaan kelembagaan tani yaitu :

1) Petani diberi kebebasan dalam pemilihan komoditas unggulan dan jenis usaha taninya

2) Meningkatkan kemandirian petani dan kelompok tani

3) Satu Gabungan Kelompok Tani (Gapoktan) dalam satu desa satu komoditi

4) Pembentukan kelembaggan petani (kelompok tani) harus mengacu pada prinsip dari petani oleh petani dan untuk petani (Anonimous, 2000).

Gernas Kakao adalah upaya percepatan peningkatan produktivitas dan mutu hasil kakao nasional melalui pemberdayaan secara optimal seluruh pemangku kepentingan serta sumberdaya yang tersedia (Anwar, 2016). Khusus di Kabupaten Bolaang Mongondow Utara Gerakan Peningkatan Produksi dan Mutu kakao dengan kegiatan meliputi: (1) Peremajaan, (2) Intensifikasi pada tahun 2011 dan kegiatan Rehabilitasi dan Intercroping pada tahun 2015 sampai dengan tahun 2016. Dasar pelaksanaan program Gernas Kakao yaitu peraturan menteri pertanian No.33/Permentan /OT.140/7/2006 tentang: Pengembangan Perkebunan melalui Program Revitalisasi Perkebunan. Program Gernas memanfaatkan tenaga pendamping untuk menyampaikan pesan dan informasi yang bersifat inovatif yang mampu memberdayakan petani. Pengawalan pelaksanaan gerakan di lapangan agar benarbenar sesuai dengan sasaran yang diharapkan, maka dalam pelaksanaannya diperlukan tenaga pendamping.Tenaga pendamping di Kabupaten Bolaang Mongodow Utara pada tahun 2011 sampai dengan 2014 tenaga pandamping sebanyak 2 (dua) orang dengan total luasan 400 ha tahun 2012. Seiring permintaan luasan areal kakao yang semakin bertambah di tahun 2015 dengan kegiatan jumlah kelompok dan total luasan 210 ha untuk (rehabilitasi) dengan 30 kelompok tani, 310 ha (intensifikasi) dengan 43 kelompok tani dan 200 ha (Intercroping) dengan 13 kelompok tani, sehingga di rekrut tenaga pendamping oleh Direktorat Jendral Perkebunan melalui Provinsi yang membidangi sebanyak 3 orang sehingga jumlah tenaga kontrak pendamping menjadi 5 orang di tahun 2015 sampai dengan sekarang.

Gernas terdiri atas tiga kegiatan utama, yaitu peremajaan, rehabilitasi, dan intensifikasi. Peremajaan, pada dasarnya merupakan upaya peningkatan produktivitas melalui penggantian tanaman kakao yang tua (rusak, tidak produktif) dengan bibit unggul dari teknik perbanyakan cloning somatic embryogenesis (SE). Rehabilitasi, upaya peningkatan produktivitas melalui perbaikan potensi genetik menggunakan teknik sambung samping bagi tanaman kakao yang produktivitasnya sangat rendah atau rusak dengan umur lebih dari 15 tahun. Intensifikasi, merupakan upaya peningkatan produktivitas melalui penerapan budi daya tanaman sesuai standar. Gernas diperlukan karena pangsa kepemilikan kebun kakao 89\% merupakan perkebunan rakyat yang tidak memiliki akses pendanaan yang memadai untuk perbaikan. Sisa $6 \%$ adalah perkebunan negara dan 5\% milik swasta. Upaya peningkatan mutu produk dan nilai tambah dapat terus dipacu seiring pemanfaatan kakao untuk bahan baku berbagai produk inovasi, seperti hasil olahan dan makananDi pihak lain, tenaga pendamping dilatih untuk melatih petani dan diharapkan dapat memberi edukasi/pengetahuan sekaligus pembelajaran terhadap para petani khususnya di bidang kakao. Pemberdayaan petani dilakukan melalui 
pelatihan dan pendampingan. Sesuai dengan keputusan Kementrian Pertanian Direktorat Jenderal Perkebunan nomor 97/Kpts/SM.340/3/2011 tentang Pengangkatan Tenaga Kontrak Pendamping (TKP) dan Pembantu Lapang Petugas Tenaga Kontrak Pendamping (PLP-TKP) Perkebunan Kegiatan Gerakan Nasional Peningkatan Produksi dan Mutu Kakao dan surat keputusan Kepala Dinas Perkebunan Propinsi Sulawesi Utara Nomor : 800/04/2012/IIa/2011 tentang Surat Pengangkatan Tenaga Kontrak Pendamping (TKP) dan Pembantu Lapang Petugas Tenaga Kontrak Pendamping (PLPTKP) Perkebunan Kegiatan Gerakan Nasional Peningkatan Produksi dan Mutu Kakao, maka tugas dan tanggungjawab petugas pendamping sebagai berikut:

1. Mengkoordinasikan penyelenggaraan penyuluhan pertanian

2. Melakukan pembinaan teknis budidaya kakao diantaranya :
a. Terdapat penaung
b. Sanitasi
c. Pemangkasan
d. Pemupukan
e. Pengendalian Hama dan Penyakit
f. Pengelolahan Pasca panen

3. Mendorong dan mengembangkan kegiatan agribisnis

4. Monitoring dan mengevaluasi kelompok tani

5. Mendampingi dan mengawal bantuan petani

6. Menginventaris dan mengidentifikasi potensi wilayah

7. Membuat laporan pelaksanaan kegiatan.Kelompok tani

Pendampingan yang dilakukan adalah kepada petani-petani yang tergabung dalam kelompok tani. Di Kabupaten Bolaang Mongondow Utara terdapat 17 kelompok tani dengan luasan 400 ha dengan kegiatan rehabilitasi, intensifikasi, dan intercropping. Pada luasan tersebut jumlah pendamping sebanyak 5 orang. Adanya pendampingan dalam pengembagan tanaman kakao menjadikan suatu hal yang menarik untuk mengkaji peranan pendampingan terhadap pengembagan kakao.

\section{Perumusan Masalah}

1. Bagaimana peran dari pendamping dalam mendampingi kelompok tani kakao di Kabupaten Bolaang Mongondow Utara?

2. Apa kendala yang dihadapi oleh pendamping dalam meningkatkan produksi dan mutu kakao di Kabupaten Bolaang Mongondow Utara?

\section{Tujuan dan Manfaat Penelitian}

Penelitian ini bertujuan untuk:

1. Untuk mengetahui peran dari pendamping sebagai objek yang memfasilitasi kelompok tani sasaran khususnya dalam bidang tanaman kakao berdasarkan tugas dan fungsi pendamping.

2. Mengetahui berbagai kendala yang dihadapi pendamping dalam kegiatan mendampingi kelompok tani di Kabupaten Bolaang Mongondow Utara.

Diharapkan Penelitiaan ini bermanfaat bagi pendamping dan sebagai bahan informasi bagi kelompok tani kakao dalam upaya pengembangan hasil dan mutu kakao dan sebagai bahan informasi bagi pemerintah dalam menentukan kebijakan untuk upaya peningkatan kesejahteraan petani kakao dan bagi peneliti sebagai penerapan teori dan konsep yang telah dipelajari selama studi.

\section{METODOLOGI PENELITIAN}

\section{Waktu dan Tempat Penelitian}

Penelitian ini dilakukan selama 3 (tiga) bulan yaitu dari bulan Februari 2017 sampai April 2017. Lokasi penelitian di Kabupaten Bolaang Mongondow Utara.

\section{Metode Pengumpulan Data}

Penelitian ini menggunakan data primer dan data sekunder. Data primer diperoleh dari wawancara langsung pada ketua kelompok tani dan anggota berdasarkan daftar pertanyaan yang telah disiapkan (kuesioner), sedangkan data sekunder diperoleh melalui Dinas Pertanian dan Kantor Kecamatan di Kabupaten Bolaang Mongondow Utara. 


\section{Metode Pengambilan Sampel}

Jumlah populasi keseluruhan 17 (tujuh belas) kelompok tani yang merupakan wilayah binaan dari pendamping dan sampel diambil 5 (lima) kelompok tani secara purposive sampling secara proporsional yaitu 3 kelompok tani kelas lanjut dan 2 kelompok tani kelas pemula. Masing-masing kelompok tani diambil 6 orang yang terdiri dari pengurus kelompok tani diantaranya ketua, sekretaris, bendahara dan 3 anggota kelompok tani sehingga jumlah keseluruhan 30 sampel.

\section{Konsep Pengukuran Variabel}

Variabel yang diukur dalam penelitian ini adalah peran pendamping berupa : Sesuai dengan keputusan Kementrian Pertanian Direktorat Jenderal Perkebunan nomor 97/Kpts/SM.340/3/2011 tugas dan tanggungjawab petugas pendamping sebagai berikut :

1. Koordinasikan penyelenggaraan penyuluhan pertanian yaitu :

a. Memotivasi petani dalam mengarahkan usaha taninya

b. Memanfaatkan kemudahan teknologi dalam berusaha tani.

c. Dapat berkomunikasi dan menyampaikan informasi dengan cepat kepada petani

d. Menyampaikan aspirasi petani

2. Penilaian pendamping sebagai teknisi dalam menerapkan budidaya kakao pada kelompok tani diantaranya :

a. Membantu dalam menyarankan tanaman penaung pada tanaman kakao.

b. Menyarankan agar melakukan sanitasi pada tanaman kakao

c. Memberikan cara pemangkasan yang baik pada tanaman kakao

d. Memberikan cara pemupukan yang baik pada tanaman kakao

e. Memantau dan mengatasi dalam pengendalian hama dan penyakit

f. Memberikan cara pengelolahan pasca panen pada kelompo tani

3. Pengembangkan kegiatan agribisnis diantaranya : a. Mengembangkan usaha tani kakao pada kelompok tani

b. Pendamping memberikan dukungan dan memberikan semangat pada kelompok dalam meningkatkan usaha kelompok tani

c. Mendorong petani dalam memberikan usaha yang lebih untung

d. Pendamping dapat mampu dalam merubah pola pikir petani tentang tanaman kakao yang menguntungkan dari sudut pandang bisnis

4. Pemonitoringan dan mengevaluasi kelompok tani dimana petugas pendamping dapat :

a. Memantau perkembangan usaha tani kakao lewat bantuan yang diberikan

b. Mengevaluasi hasil perkembangan tanaman kakao berdasarkan mutu dan produksi

5. Penilaian pendamping dalam mendampingi dan mengawal bantuan yang disalurkan kepada kelompok tani sampai pada petani sasaran

a. Peran pendamping dalam mengawal dan mendampingi bantuan yang disalurkan kepada kelompok tani

b. Peran Pendamping dalam mengawal dan mendampingi bantuan yang di salurkan pada anggota kelompok tani

6. Penilaian pendamping dalam menginventaris dan mengidentifikasi potensi wilayah

7. Penilaian pendamping dalam membuat laporan pelaksanaan kegiatan

\section{Metode Analisis Data}

Data yang diamati dan diukur dalam penelitian ini adalah peran pendamping perkebunan dalam pemberdayaan kelompok tani kakao, dianalisis secara deskriptif. Gambaran serta keadaan/kondisi nyata kelompok-kelompok tani, digunakan melalui tabulasi dimana skor responden dijumlahkan, kemudian dihitung tingkat peranannya yang ditafsirkan sebagai posisi penilaian responden pada Skala Likert. 


\section{HASIL DAN PEMBAHASAN}

\section{Deskripsi Wilayah Penelitian}

Luas Kabupaten Bolaang Mongondow Utara adalah sebuah kabupaten seluas 1.852,86 $\mathrm{km}^{2}$ dan memi liki 106 desa. Tiap kelurahan terdiri atas 6 kecamatan. Ibukota dari kabupaten ini yaitu Boroko. Kabupaten ini disetujui pemekarannya oleh Dewan Perwakilan Rakyat pada tanggal 8 Desember 2006 dan diresmikan tanggal 2 Januari 2007 dengan dasar hukum Undang-Undang Republik Indonesia No. 10/2007. Jumlah penduduk 74.191 jiwa pada tahun 2014, dengan kepadatan penduduk rata-rata 39 jiwa $/ \mathrm{km}^{2}$. Penduduk asli kabupaten ini adalah Suku Kaidipang dan Suku Bintauna. Hal ini menyebabkan terdapat dua bahasa daerahyaitu bahasa Kaidipang dan bahasa Bintauna Terdapat 1 Rumah Sakit di Kecamatan Bolaang Itang Barat, 11 Puskesmas dan 16 Puskesmas Pembantu yang tersebar di kabupaten ini. Penduduk Kabupaten Bolaang Mongondow Utara mayoritas beragama Islam sekitar 88,85 persen dan sisanya 11,15 persen beragama non Islam. Adapun sarana pendidikan yang ada di kabupaten ini yang paling banyak yaitu TK/RA sebanyak 93 buah diikuti Sekolah Dasar 86 buah. Madrasah Ibtidayah 9 buah, SMP sejumlah 19 buah, Madrasah Tsanawiyah sebanyak 7 buah dan SMA/MA/SMK berjumlah 10 buah.

\section{a. Umur Responden}

\section{Deskripsi Responden}

Responden petani kakao yang berumur antara 30 dan 50 tahun. Petani yang berumur kurang dari 30 tahun berjumlah 2 orang $(6,7 \%)$, yang berumur 30 tahun sampai 50 tahun berjumlah 24 orang (80\%) dan umur lebih dari 50 tahun berjumlah 4 orang $(13,3 \%)$ sehingga dapat disimpulkan bahwa rata-rata umur petani pada 5 kelompok tani kakao masih dalam kategori produktif dengan kemampuan fisik untuk melakukan pekerjaan di dalam usaha tani masih tinggi.

\section{b. Tingkat pendidikan Responden}

Tingakt pendidikan tertinggi petani responden adalah SMA yang mendominasi yaitu sebanyak 17 petani $(56,7 \%)$, sedangkan petani berpendidikan SLTP sebanyak 8 orang $(26,6 \%)$ dan pendidikan SD sebanyak 5 orang $(16,7 \%)$

\section{c. Pekerjaan Responden}

Pekerjaan dari responden yaitu semuanya adalah petani yang memiliki tanaman kakao dan mengelolah usaha tani kakao walaupun dalam kebun milik sendiri petani tersebut juga memiliki tanaman lain untuk menunjang hidup keluarga. Adapun tanaman lain yang diusahakan selain kakao yaitu pisang, kelapa, pala dan cengkih.

\section{Profil Kelompok Tani}

Identitas dan karakteristik kelompok tani responden terdiri dari 5 kelompok tani pada 4 kecamatan di Kabupaten Bolaang Mongodow Utara meliputi : nama kelompok tani, tahun berdiri, jumlah anggota, luas lahan, jenis usaha tani ditunjukkan pada Tabel 1 .

\section{1) Kelompok Tani Tenggang Rasa}

Kelompok Tani Tenggang Rasa berdiri pada tahun 2011 yang pada awalnya memiliki nama Pomomuntula. Pada tahun 2012 sesuai kesepakatan mengganti nama kelompok tani Tenggang Rasa dengan satu komoditi perkebunan yaitu kakao. Kelompok tani Tenggang Rasa saat ini diketuai oleh Bapak. Rahmat Gumohung. kegiatan intensifikasi dimana kelompok mengharapkan pemeliharaan yang berkelanjutan. Kelompok tani ini memiliki luas lahan 22 ha dengan 15 orang anggota

\section{2) Kelompok Tani Tomukalang}

Kelompok tani Tomukalang berdiri pada tahun 2008 yang pada awalnya adalah kelompok tani dengan kumpulan petani-petani padi sawah kelompok tani Tomukalang ini adalah kelompok tani pertama yang di bentuk di desa Dengi. Kelompok tani Tomukalang saat ini diketuai oleh Bapak. Ahmad Abdulah. Kelompok tani Tomukalang mendapat kegiatan intensifikasi tanaman kakao dimana kegiatan ini mengutamakan pemeliharaan lanjutan dari tanaman kakao dengan produksi yang relatif masih kurang.

\section{3) Kelompok Tani Melati}

Kelompok Tani Melati pada tahun 2011 diketuai oleh Bapak Masjun Paputungan dan kemudian pada tahun 2015 diganti oleh Bapak. Yusran Tongkingoto. berada di Desa Paku Induk yang berdiri pada tahun 2011 sejak awal dari program Gernas Kakao yang pada saat itu tergabung dalam kegiatan intensifikasi dengan nama Inaulas Bersatu. 
Tabel 1. Profil Kelompok Tani sebagai responden

\begin{tabular}{cccccccc}
\hline No & $\begin{array}{c}\text { Kelompok } \\
\text { Tani }\end{array}$ & Desa & Kecamatan & $\begin{array}{c}\text { Tahun } \\
\text { Berdiri }\end{array}$ & $\begin{array}{c}\text { Jumlah } \\
\text { anggota }\end{array}$ & luas lahan & Kegiatan \\
\hline 1 & $\begin{array}{c}\text { Tenggang } \\
\text { Rasa }\end{array}$ & Innomunga & Kaidipang & 2012 & 15 & $22 \mathrm{Ha}$ & Intensifikasi \\
2 & Cokelat & Bigo & Kaidipang & 2012 & 10 & $10 \mathrm{Ha}$ & Intensifikasi \\
3 & Tbadi & Selatan & Pinogaluman & 2011 & 10 & $10 \mathrm{Ha}$ & Intensifikasi \\
4 & Melati & Paku Induk & $\begin{array}{c}\text { Bolangitang } \\
\text { Barat }\end{array}$ & 2015 & 15 & $16 \mathrm{Ha}$ & Rehabilitasi \\
5 & Maju & Mokoditek & $\begin{array}{c}\text { Bolangitang } \\
\text { Timur }\end{array}$ & 2015 & 20 & $28 \mathrm{Ha}$ & Rehabilitasi \\
\hline
\end{tabular}

\section{4) Kelompok Tani Maju Bersama}

Kelompok tani ini berdiri pada tahun 2015 dengan ketua ketuai oleh Bapak Windert Wungkana yang juga sebagai pendiri dari kelompok tani dan terdaftar pada program Pengembangan Tanaman Kakao tahun 2015 sesuai dengan SK Kepala Dinas Perkebunan Propinsi Sulawesi Utara. Awal terbentuk kelompok tani ini karena banyak petani kakao di desa Mokoditek yang mempunyai tanaman kakao yang sudah tua dan tidak berproduksi lagi.

\section{5) Kelompok Tani Cokelat Abadi}

Ketua kelompok tani Cokelat Abadi adalah Bapak Abas Gumohung. Kelompok tani ini tergolong dalam tingkat kelas lanjutan. Kelompok tani Cokelat Abadi adalah kelompok tani yang terbentuk pada tahun 2012. Awal dibentuknya kelompok tani Cokelat Abadi ini karena adanya kebersamaan satu tujuan untuk meningkatkan hasil dari tanaman kakao yang dimiliki.

\section{Kegiatan Pendampingan}

Kunci Keberhasilan program pemerintah Gerakan Peningkatan Produksi dan Mutu Kakao (Gernas Kakao) sangat ditentukan oleh dukungan dan peran aktif dari petani dalam melaksanakan usaha taninya, serta keaktifan pendamping pada wilayah binaan, sehingga kegiatan usaha tani kakao tidak lagi untuk meningkatkan produksi, mencukupi kebutuhan konsumsi petani tetapi sudah berorientasi pada agribisnis yang pada akhirnya dapat meningkatkan pendapatan petani dan kesejahteraan petani dan keluarga meningkat. teknologi berupa memotivasi petani untuk lebih memperhatikan kakao sebagai tanaman
Akan tetapi pada kenyaataan di lapangan belum semua anggota yang tergabung dalam kelomok tani dapat mengikutinya dikarenakan sulitnya untuk mengadakan pertemuan di kelompok tani masing-masing ini disebabkan karena kesibukan yang berbeda-beda juga akses lokasi kebun yang jauh yang pada kenyataannya sangat menghalangi anggota untuk aktif dalam kelompok. Hal ini juga membedakan banyaknya pertemuan yang dilakukan pendamping kakao pada masingmasing kelompok tani. Jenis program kegiatan yang diberikan pada masing-masing kelompok tani pada dasarnya adalah sama, akan tetapi yang membedakan adalah jumlah dan waktu kegiatan yang diikuti oleh kelompok tani.

\section{Peran Pendamping dalam Pemberdayaan Kelompok Tani}

Salah satu faktor keberhasilan dalam pelaksanaan program gernas kakao adalah peran pendamping. Hasil analisis menunjukkan bahwa pendamping sangat berperan dalam peningkatan pengetahuan petani. Secara rinci peran pendamping dapat dilihat pada uraian berikut:

1) Pendamping sebagai koordinator penyelenggaraan penyuluhan pertanian

Peran pendamping sebagai koordinator diperoleh berdasarkan penilain dari petani responden dapat dilihat pada Tabel 2. Tabel 2 menunjukkan bahwa pendamping sangat berperan dalam penyuluhan baik dalam memotivasi, mendorong penggunaan yang bernilai ekonomis, memanfaatkan dan menerapkan teknologi-teknologi yang telah 
diberikan. Demikian juga informasiinformasi penting untuk petani

2) Pendamping sebagai pembina teknis budidaya kakao

Berdasarkan penilaian petani responden yang dituangkan dalam Tabel 3, maka dapat disimpulkan bahwa pendamping sangat berperan sebagai pembina teknis budidaya. Tabel 3 menunjukkan bahwa pendamping sudah berfungsi dengan sangat baik dalam membina petani untuk memberikan naungan pada tanaman kakao, mengadakan sanitas, pemangkasan, pemupukan, pengendalian hama dan penyakit juga penolahan pasca panen dengan teknik fermentasi.

3) Pendamping sebagai pengembang kegiatan agribisnis

Petani responden memberikan penilaian yang sangat baik terhadap peran pendamping sebagai pengembangan kegiatan agribisnis. Penilaian tersebut dapat dilihat pada Tabel 4. Tabel 4 menunjukkan bahwa pendamping sangat berperan terhadap pendampingan usahatani kelompok tani, menyemangati dalam mengembangkan kakao sebagai komoditi yang lebih menguntungkan, dan mulai mengubah pola pikir petani dari pola pikir produktif ke arah pola pikir agribisnis

Tabel 2. Peran pendamping sebagai koordinator penelenggara penyuluhan.

\begin{tabular}{|c|c|c|c|c|}
\hline No & Pernyataan & Total Skor (+) & Total Skor (-) & Tingkat Peranan \\
\hline 1 & $\begin{array}{l}\text { Peran pendamping memotivasi } \\
\text { petani dalam mengarahkan usaha } \\
\text { tani }\end{array}$ & 137 & 125 & Sangat Berperan \\
\hline 2 & $\begin{array}{l}\text { Peran pendamping dalam } \\
\text { mendorong petani dan } \\
\text { memanfaatkan kemudahan } \\
\text { teknologi }\end{array}$ & 140 & 134 & Sangat Berperan \\
\hline 3 & $\begin{array}{l}\text { Berkomunikasi dalam } \\
\text { menyampaikan informasi dengan } \\
\text { cepat kepada petani }\end{array}$ & 136 & 132 & Sangat Berpran \\
\hline 4 & $\begin{array}{l}\text { Peran pendamping dalam } \\
\text { menyampaikan aspirasi petani }\end{array}$ & 135 & 131 & Sangat berperan \\
\hline
\end{tabular}

Tabel 3. Peran Pendamping sebagai Pembina Teknis Budidaya Kakao

\begin{tabular}{clccc}
\hline No & Pernyataan & $\begin{array}{c}\text { Total Skor } \\
(+)\end{array}$ & Total Skor (-) & Tingkat Peran \\
\hline 1 & $\begin{array}{l}\text { Menyarankan tanaman penaung pada } \\
\text { setiap perkebunan kakao kelompok tani. }\end{array}$ & 128 & 130 & Sangat Berperan \\
2 & $\begin{array}{l}\text { Menyarankan petani agar melakukan } \\
\text { sanitasi pada setiap perkebunan kakao }\end{array}$ & 121 & 139 & $\begin{array}{c}\text { Sangat } \\
\text { Berperan } \\
\text { Sangat }\end{array}$ \\
3 & $\begin{array}{l}\text { Memberikan cara pemangkasan yang baik } \\
\text { pada tanaman kakao }\end{array}$ & 129 & 145 & $\begin{array}{c}\text { Berperan } \\
\text { Memberikan cara pemupukan yang baik }\end{array}$ \\
$\begin{array}{l}\text { pada tanaman kakao } \\
\text { Memantau dan mengatasi dalam } \\
\text { pengendalian hama dan penyakit }\end{array}$ & 128 & 141 & Sangat Berperan \\
6 & Memberikan cara pengolahan pasca panen & 120 & 135 & Sangat Berperan \\
\hline
\end{tabular}


4) Pendamping sebagai pelaksana monitoring dan evaluasi

Peran pendamping sebagai pelaksana dan evaluasi kegiatan gernas dinilai responden telah dijalankan dengan sangat baik yang terlihat pada tabel 5. Tabel 5 menunjukkan bahwa evaluasi dan monitoring pengembangan usahatani kakao berdasarkan mutu telah dilakukan setiap saat, baik saat kunjungan maupun saat petani membutuhkan bantuan pendampingan
5) Pendamping sebagai pengawal bantunan petani

Petani responden menilai bahwa dalam pemberian bantuan pendamping selalu mengadakan pemantauan dengan sangat baik yang dapat dilihat pada tabel 6. Pemberian bantuan yang diterima kelompok tani selalu dipantau perkembangannya baik terhadap kelompok maupun terhadap angota kelompok.

Tabel 4. Peran pendamping sebagai Pengembang Agribisnis

\begin{tabular}{|c|c|c|c|c|}
\hline No & Pernyataan & Total Skor (+) & Total Skor (-) & Tingkat Peranan \\
\hline 1 & $\begin{array}{l}\text { Pendamping mengembangkan usahatani } \\
\text { pada kelompok tani }\end{array}$ & 134 & 123 & Sangat berperan \\
\hline 2 & $\begin{array}{l}\text { Pendamping memberikan dukungan dan } \\
\text { semangat pada kelompok }\end{array}$ & 142 & 132 & Sangat berperan \\
\hline 3 & $\begin{array}{l}\text { Pendamping mendorong petani dalam } \\
\text { memberikan usaha yang lebih untung }\end{array}$ & 138 & 131 & Sangat berperan \\
\hline 4 & $\begin{array}{l}\text { Pendamping dapat mampu merubah pola } \\
\text { pikir petani dimana kakao adalah tanaman } \\
\text { yang menguntungkan }\end{array}$ & 130 & 128 & Sangat berperan \\
\hline
\end{tabular}

Tabel 5. Peran pendamping sebagai pelaksana Monitoring dan Evaluasi

\begin{tabular}{llccc}
\hline No & Pernyataan & Total Skor $(+)$ & Total Skor (-) & Tingkat Peran \\
\hline 1 & $\begin{array}{l}\text { Pendamping memantau perkembangan } \\
\text { usaha tani kakao lewat bantuan yang } \\
\text { diberikan }\end{array}$ & 138 & 121 & Sangat Berperan \\
2 & $\begin{array}{l}\text { Pendamping mengevaluasi hasil } \\
\text { perkembangan tanaman kakao } \\
\text { berdasarkan mutu dan produksi }\end{array}$ & 121 & 140 & Sangat Berperan \\
\hline
\end{tabular}

Tabel 6. Peran Pendamping sebagai Pengawal Bantuan

\begin{tabular}{llccc}
\hline No & Pernyataan & Total Skor $(+)$ & Total Skor (-) & Tingkat Peran \\
\hline 1 & $\begin{array}{l}\text { Pendamping memantau } \\
\text { perkembangan usaha tani kakao } \\
\text { lewat bantuan yang diberikan }\end{array}$ & 138 & 121 & Sangat Berperan \\
2 & $\begin{array}{l}\text { Pendamping mengevaluasi hasil } \\
\text { perkembangan tanaman kakao } \\
\text { berdasarkan mutu dan produksi }\end{array}$ & 121 & 140 & Sangat Berperan \\
\hline
\end{tabular}

Tabel 7. Peran pendamping dalam inventaris dan identifikasi Potensi wilayah

\begin{tabular}{lcccc}
\hline $\begin{array}{l}\text { Alternatif } \\
\text { Jawaban }\end{array}$ & Alternatif Skor & Jumlah Responden & Total Skor & Persentase (\%) \\
\hline Sangat Berperan & 5 & 8 & 40 & 26,7 \\
Berperan & 4 & 22 & 88 & 73,3 \\
Cukup & 3 & - & - & - \\
Kurang Berperan & 2 & - & - & - \\
Tidak Berperan & 1 & - & - & - \\
\hline Total & & 30 & 128 & 100,0 \\
\hline
\end{tabular}


Tabel 8. Peran pendamping sebagai Pembuat laporan

\begin{tabular}{lcccc}
\hline $\begin{array}{c}\text { Alternatif } \\
\text { Jawaban }\end{array}$ & Alternatif Skor & Jumlah Responden & Total Skor & Persentase (\%) \\
\hline Sangat Berperan & 5 & 19 & 95 & 63,3 \\
Berperan & 4 & 11 & 44 & 36,7 \\
Cukup & 3 & & - & - \\
Kurang Berperan & 2 & & - & - \\
Tidak Berperan & 1 & 30 & 139 & 100,0 \\
\hline Total & & & \\
\hline
\end{tabular}

6) Pendamping melakukan identifikasi

Tabel 7 menunjukkan bahwa pendamping berperan dalam melakukan inventarisasi dan identifikasi poternsi wilayah. Peran pendamping dalam menginventaris dan mengindentifikasi potensi wilayah masih perlu ditingkatkan karena $73,3 \%$ petani masih belum memberikan tingkat kepuasan yang sangat tinggi.

7) Pendamping Pembuat laporan Pelaksana Kegiatan

Laporan merupakan suatu hal yang penting dalam kegiatan gernas kakao,karena melalui laporan, maka kegiatan yang telah dilakukan dapat teridentifikasi. Penilaian responden terhadap hal ini dituangkan dalam tabel 8. Tabel 8 menunjukkan bahwa pendamping telah membuat laporan dengan baik karena tidak ada responden yang memberikan nilai kurang. Namun diharapkan bahwa pendamping lebih intesif lagi dalam pembuatan laporan karena 36,7 \% responden masih mengharapkan peningkatan peran ini. Secara keseluruhan dapat dikatakan bahwa pendamping telah berperan sangat baik dalam program gernas kako dengan diperolehnya tingkat peran pendamping sebesar 88,9 persen.

\section{KESIMPULAN DAN SARAN}

\section{Kesimpulan}

Pendamping sangat berperan dalam memberdayakan kelompok tani kakao baik pada tingkat pemula maupun lanjut dalam kegiatan intensifikasi dan rehabilitasi pada program Gernas Kakao (Gerakan Peningkatan Produksi dan Mutu Kakao) di Kabupaten Bolaang Mongondow Utara dalam hal mengkoordinasikan penyelenggaraan penyuluhan pertanian, melakukan pembinaan teknis budidaya kakao, mendorong dan mengembangkan kegiatan agribisnis, memonitoring dan mengevaluasi kelompok tani, mendampingi dan mengawal bantuan petani, dan perlu peningkatan peran dalam menginventaris dan mengidentifikasi potensi wilayah serta dalam membuat laporan pelaksanaan kegiatan. Peran pendamping tergolong pada kategori sangat berperan yaitu $88,9 \%$. Kendala yang dihadapi oleh pendamping di lapangan yaitu petani yang masih takut akan resiko kegagalan dalam produksi sehingga belum bisa menerima teknologi-teknologi baru yang diberikan dan lebih memilih untuk mengusahakan tanaman dengan cara sendiri, hal ini terjadi pada kelompok tani pemula. Kurangnya koordinasi sehingga pendamping sangat sulit dalam merubah pola pikir petani karena petani masih terpaku dan hanya mengharapkan bantuan dari pemerintah.

\section{Saran}

Kepada pendamping untuk lebih intensif meningkatkan peran dalam mendampingi kelompok tani yang belum mandiri ke arah mandiri sehingga lebih baik dalam pengambilan keputusan dan bagi petani agar tidak selalu tergantung pada bantuan pemerintah sehingga menjadi kelompok tani yang lebih maju. Untuk mengatasi kendala pendamping mengingat kelompok tani yang banyak sehingga pendamping tidak efisien dalam mendampingi kelompok, untuk itu diperlukan peran dari pemerintah pusat untuk penambahan tenaga pendamping dalam menunjang kelompok tani. 


\section{DAFTAR PUSTAKA}

Anonimous. 2000. Pengembangan SDM Pertanian dan Keswadayaan Petani Nelayan. Volume 12. Ekstensia.

Anonimous. 2010. Pedoman Pemberdayaan Masyarakat Tani dalam Pengembangan Agribisnis. Pusat Penyuluhan Pertanian Badan Penyuluhan dan Pengembangan SDM Pertanian Kementerian Pertanian.

Anonimous. 2010. Hubungan Kerja Penyuluh Pendamping dan Penyelia Mitra Tani (PMT). Pusat Pengembangan Penyuluhan Pertanian Badan Penyuluhan dan Pengembangan SDM Kementerian Pertanian.

Anonimous. 2012. Pedoman Teknis Peningkatan Produksi dan Mutu Tanaman Rempah dan Penyegar. Direktorat Jenderal Perkebunan Kementerian Pertanian.

Azwar A. Bakar. 2015. Membuat Petani Kakao Tersenyum. Bypass

Badeni. 2014. Kepemimpinan dan Perilaku Organisasi. Alfabeta. Bandung

BPS. 2014. Kabupaten Bolaang Mongondow Utara Dalam Angka 2014. BPS Kabupaten Bolaang Mongondow.

Donni, Juni. 2016. Perencanaan dan Pengembangan Sumber Daya Manusia. Alfabeta. Bandung

Indraningsi, Kurnia., Sugihen, S dan Basita. G. 2010. Kinerja Penyuluh dari Prespektif Petani dan Eksistensi Penyuluh Swadaya sebagai Pendamping Penyuluh Pertanian. Analisis Kebijakan Pertanian. Vol. 8 Nomor 4 (diakses 10 November 2016).
Muklishah. N dan Saleh. A. 2014. Aktifitas Komunikasi Organisani dan Kinerja Pendamping dalam Program Gerakan Nasional Kakao di Kabupaten Polewali Mandar. Vol.12, No. 2. (diakses 14 Desember 2016).

Nasdian. F. T. 2015. Pengembangan Masyarakat. Departemen Sains Komunikasi dan Pengembangan Masyarakat Fakultas Ekologi Manusia, IPB dengan Yayasan Pustaka Obor Indonesia.

Nuhung. I. A. 2003. Membangun Pertanian Masa Depan. Aneka Ilmu, anggota IKAPI.

Rahmat. Rukmana. 2016. Untung Selangit dari Agribisnis Kakao. Lily Publisher.

Saleh. A. A. 2016. Bangga dengan Kakao Indonesia. PT. Gramedia. Jakarta.

Sedarmayanti. 2014. Restrukturisasi dan Pemberdayaan Organisasi. PT Rafika Aditama.

Sugiyono. 2016. Metode Penelitian dan Pengembangan. Alfabeta. Bandung.

Suryantini. H. 2003. Kebutuhan Informasi dan Motivasi Kognitif Penyuluh Pertanian serta Hubungannya dengan Penggunaan Sumber Informasi. Vol.12, Nomor 2.

Stepanus, Malinau. 2011. Peranan Kelompok Tani dalam Meningkatkan Pendapatan Usaha Tani Padi Sawah (Oryza sativa, L.) di Desa Bukit Pariaman Kecamatan Tenggarong Seberang Kabupaten Kutai Kartanegara. Vol. 4 No.1.

Theresia. A. dan Mardikanto. Totok. 2015. Pembangunan Berbasis Masyarakat. Alfabeta, Bandung.

Van den Ban A. W dan Hawkins. H. S. 1999. Penyuluhan Pertanian. Kanisus. Yogyakarta. 